\title{
COMMUNITY PERCEPTIONS ON THE MANAGEMENT OF GEDAMBAAN BEACH TOURISM OBJECTS IN KOTABARU REGENCY, SOUTH KALIMANTAN, INDONESIA
}

\author{
Achmad Syamsu Hidayat ${ }^{1 凶}$, Leila Ariyani Sofia ${ }^{1}$, Erma Agusliani ${ }^{1}$ \\ ${ }^{1}$ Faculty of Fisheries and Marine, Lambung Mangkurat University, Banjarmasin, South Kalimantan, \\ Indonesia.
}

\section{ABSTRACT}

Gedambaan Village is one of the villages that has tourism potential in Kotabaru Regency, namely Gedambaan Beach. This beach offers two natural atmospheres that can be enjoyed simultaneously, namely views of green mountains and expanses of sea decorated with bagang fishermen, and equipped with various adequate facilities and infrastructure. The existence of coastal tourism will have a positive impact on the local community if they can participate in taking advantage of it as a new business opportunity. On the other hand, this condition will have a negative impact on their livelihoods and will only reduce the ecological quality of the coast if all economic actors there are not able to maintain the environmental sustainability. This study aims to analyze community perceptions of the management of Gedambaan Beach tourism objects. The sample in this study amounted to 101 respondents consisting of 78 local people (approach with the Slovin formula to the number of family heads) and as many as 23 people (census) tourism object managers. Perception analysis was carried out descriptively using a Likert scale calculation. The results of the study showed that the local community feels that the existence of Gedambaan beach tourism did not provide job opportunities and business opportunities for them, while they were of the view that the management of the beach tourism needs support, good relations, and involvement of the local community, especially in environmental conservation.

Hnding: This research receiver specific grant from any funding agency in the public, commercial, or not-for-profit sectors.

Copyright: (C) 2021 The Author(s). This is an open access article distributed under the terms of the Creative Commons Attribution License, which permits unrestricted use, distribution, and reproduction in any medium, provided the original author and source are credited.

Keywords: Gedambaan Beach, Beach Tourism, Community Perception

\section{INTRODUTION}

Tourism is one of the potential sectors to be developed as a source of state income. The development of tourism not only has an impact on the country's foreign exchange but also provides opportunities for doing business and creating jobs (Surwiyanta (2003)). The development of tourism resources and potential is expected to be able to contribute to economic income. The arrival of tourists to a tourist spot or Tourism Destination Areas (TDA) can also provide welfare for the local population.

Kotabaru Regency is one of the regencies located in South Kalimantan which is located in the eastern part with an area of 9.422,46 km2 or more than a quarter $(25.11 \%)$ of the total area of South Kalimantan Province. Kotabaru Regency consists of one large island and has 110 clusters of small islands, 31 of which have not been named. In addition, this district is a sea shipping lane, because it is directly adjacent to the Makassar Strait and the Java Sea. This condition is a potential for the development of Kotabaru

How to cite this article (APA): Hidayat, A. S., Sofia, L. A., and Agusliani, E. (2021). Community Perceptions on the Management of Gedambaan Beach Tourism Objects in Kotabaru Regency, South Kalimantan, Indonesia. International Journal of Engineering Technologies and Management Research, 8(10), 88-98. doi: 10.29121/ijetmr.v8.i10.2021.1051 
tourism (Regional Development Planning Agency of Kotabaru Regency (2017)). The natural potential with its flora can be used as nature tourism. The vast expanse of the coast and the cluster of small islands can have great potential to be developed as marine tourism "Nautical". The number of tourist visits in the last 10 years has shown an increasing trend (Figure 1).

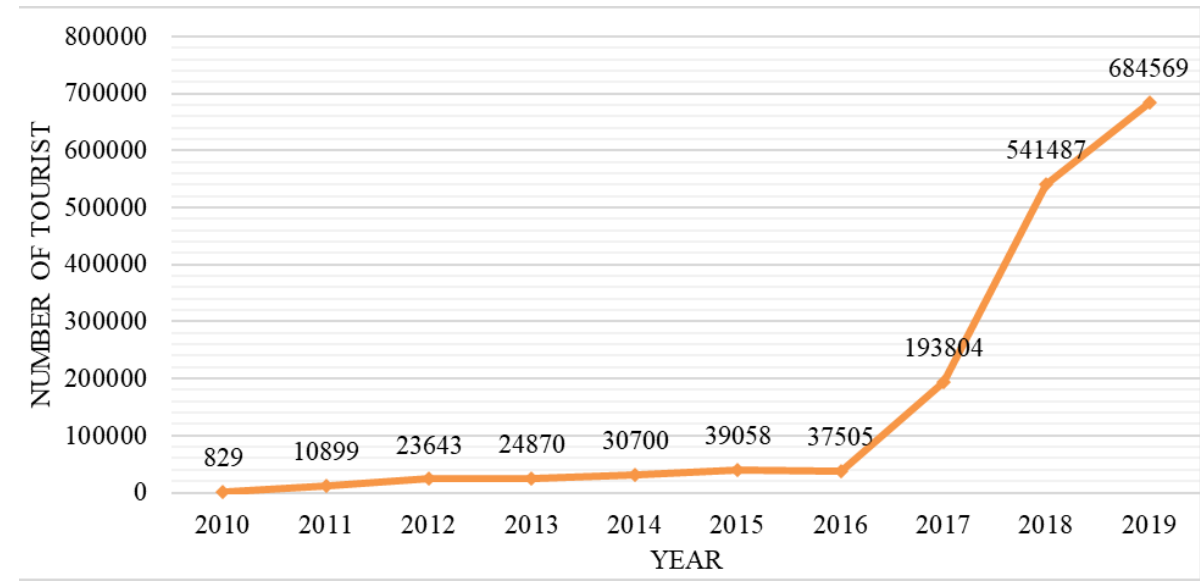

Figure 1 The development of tourist visits in Kotabaru, South Kalimantan, Indonesia

Gedambaan Beach tourism object is a tour managed by the Kotabaru Regency Government. The development of tourism began around 1990 but did not have a clear development direction until 2003 when infrastructure reform activities began to be rebuilt. Gedambaan Beach is located in Gedambaan Village, North Laut Island District, which is approximately $14 \mathrm{~km}$ from the capital city of Kotabaru Regency. The Gedambaan beach tourist attraction offers very beautiful natural beauty, in the east, there are mountains full of green trees and in the west, you can see the sunrise, the location of the tourist attraction is on the coast of Laut Island with Sebuku Island having small wave currents so it has no effect on activity on the beach and does not require a breakwater. This condition makes swimming tourism activities at Gedambaan Beach safer (UKK BPP (2017); Irhamm (2020)).

As the tourist attraction develops, more and more problems arise both from visitors and the local community. Some of these problems, such as the destruction of the ecosystem in the form of shortcuts to avoid paying entrance tickets. Differences in parking rates on big days cause anxiety for visitors.

The existence of coastal tourism will have a positive impact on the local community if they can participate in taking advantage of it as a new business opportunity. On the other hand, this condition will have a negative impact on their livelihoods and will only reduce the ecological quality of the coast if all economic actors are not able to maintain environmental sustainability (Lopes et al. (2015); Wu and Tsai (2016); Suardana and Sudiarta (2017); Khrisnamurti et al. (2017); Maliao et al (2017).

Based on the above conditions, whether the management of the Gedambaan beach tourism object which has been managed by employees of the Department 
Tourism, Youth and Sports of Kotabaru Regency has involved the local community to provide work opportunities and business opportunities for them. The purpose of this study is to analyze how the public's perception of the existence of the Gedambaan Beach tourist attraction area.

\section{MATERIALS AND METHODS}

This research was conducted from January to April 2021 in Gedambaan Village, North Laut Island District, Kotabaru Regency, South Kalimantan Province, Indonesia. This study used two types of data, namely primary data and secondary data. Primary data was collected directly at the research location through observation, interviews, questionnaires, and documentation, while secondary data was obtained from the Gedambaan Village Profile Book, Gedambaan Beach Visitor Record Book, Kotabaru Regency Tourism Object Book, and the results of other relevant previous studies.

Respondents in this study were local people (family heads) who lived in Gedambaan Village. The number of samples used in this study was 78 people, the determination of the number of respondents who used the Slovin formula approach with an error level of 10\%. The Slovin formula (Sugiyono, 2011) using equation 1.

$$
\mathrm{n}=\frac{\mathrm{N}}{1+\left(\mathrm{N} \mathrm{x} \mathrm{e}^{\wedge 2}\right)}
$$

$$
\begin{aligned}
& \text { Where, } \\
& \begin{array}{l}
\mathrm{n}=\text { Number of samples } \\
\mathrm{N} \quad=\text { Total population } \\
\mathrm{e} \quad=\text { Error tolerance }
\end{array}
\end{aligned}
$$

\section{Descriptive analysis of community perception}

\begin{tabular}{|c|c|c|}
\hline No. & Statement & Score \\
\hline 1. & Strongly Agree (SA) & 5 \\
\hline 2. & Agree (A) & 4 \\
\hline 3. & Neither agree nor disagree (NAND) & 3 \\
\hline 4. & Disagree (D) & 2 \\
\hline 5. & Strongly Disagree (SD) & 1 \\
\hline
\end{tabular}

Data analysis for assessing community perceptions of the existence of Gedambaan Tourism Beach used a quantitative descriptive method, namely by scoring from the Likert scale on the answers of all respondents (Table 1) (Metri et al., 2018).

All respondents' answers were calculated using the following equation 2 for each question item.

$$
\% \text { Community Perception }=\frac{\text { Total score of respondents }}{\text { Total highest score }} \times 100 \%
$$


The percentage of results was interpreted based on the following criteria (Riduwan \& Sunarto, 2013):

$$
\begin{array}{ll}
\text { Number of } \leq 20 \% & =\text { Strongly Disagree (SD) } \\
\text { Number of }>20-40 \% & =\text { Disagree (D) } \\
\text { Number of }>40 \%-60 \% & =\text { Neither agree nor disagree (NAND) } \\
\text { Number of }>60 \%-80 \% & =\text { Agree (A) } \\
\text { Number of }>80 \%-100 \% & =\text { Strongly Agree (SA) }
\end{array}
$$

In this study, 10 questions were asked regarding the management of Gedambaan Beach tourism with the involvement of the surrounding community and their perceived impact. The ten questions are as follows:

1) Does the existence of the Gedambaan beach tourism object have a positive impact on the household economy of the local community?

2) Does the Gedambaan beach attraction provide job opportunities for the local community?

3) Is local community participation needed in its development?

4) Is it necessary to involve the local community in the conservation of the surrounding environment?

5) Are socialization and training needed to increase community skills in supporting the development of tourism areas?

6) Is there a need for a good relationship between the manager and the local community?

7) Are local people absorbed as labor in the management of this beach tourism object?

8) Does the existence of this Gedambaan beach attraction open up business opportunities for the local community?

9) Does the local community support the development of this Gedambaan beach attraction?

10) Do people know that the development of this tourist attraction is a tourism industry?

\section{RESULTS AND DISCUSSIONS}

\section{Natural potential in Gedambaan Village}

Gedambaan Village has very interesting natural potential. Along the road entering the village area, you can see a green mountain forest area on the right side of the road, namely Mount Mamake (Figure 2), and on the left side of the road you can see a vast expanse of ocean decorated with bagang fisherman. Gedambaan Beach was formerly often called Tiung's Nest Beach, it was said that the story is that many Tiung Birds are living on this beach, so it is called "Tiung's Nest". In 2012, the government expanded Sarang Tiung Village, a tourist attraction that was originally located in Sarang Tiung Village after the expansion of the village, the tour was entered in Gedambaan Village. Now the tourist attraction is called Gedambaan Beach (Figure 3) which comes from the name of the village where the tour is located. The beach manager interprets the name "Gedambaan" as a term from "Dambaan", namely Dambaan Beach for the community. 

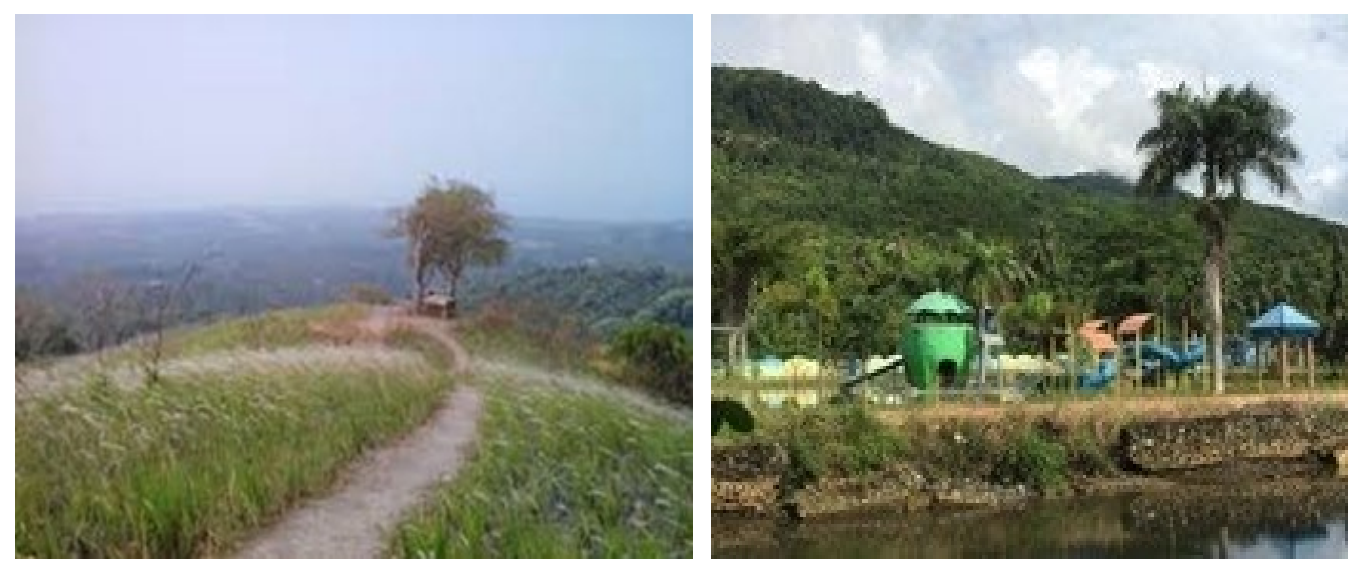

Figure 2 Mount Mamake, South Kalimantan, Indonesia

Visitors can enjoy the beautiful view of the beach and also the beautiful nature of the mountains which are beautiful and green at the same time in one place. The Gedambaan beach tourism area has provided adequate facilities and infrastructure such as an information center, control tower, cottages, open stage, prayer room, gazebo, food and gift stalls, photo spots, playgrounds, and toilets in the form of boats, and swimming pool rides which will soon be reopened after being renovated.

Gedambaan Beach not only provides a variety of comfortable and complete facilities and offers beautiful views, but the manager was also very concerned about the cleanliness of the environment around the tourist attraction to ensure the comfort of visitors with adequate environmental hygiene supporting facilities.
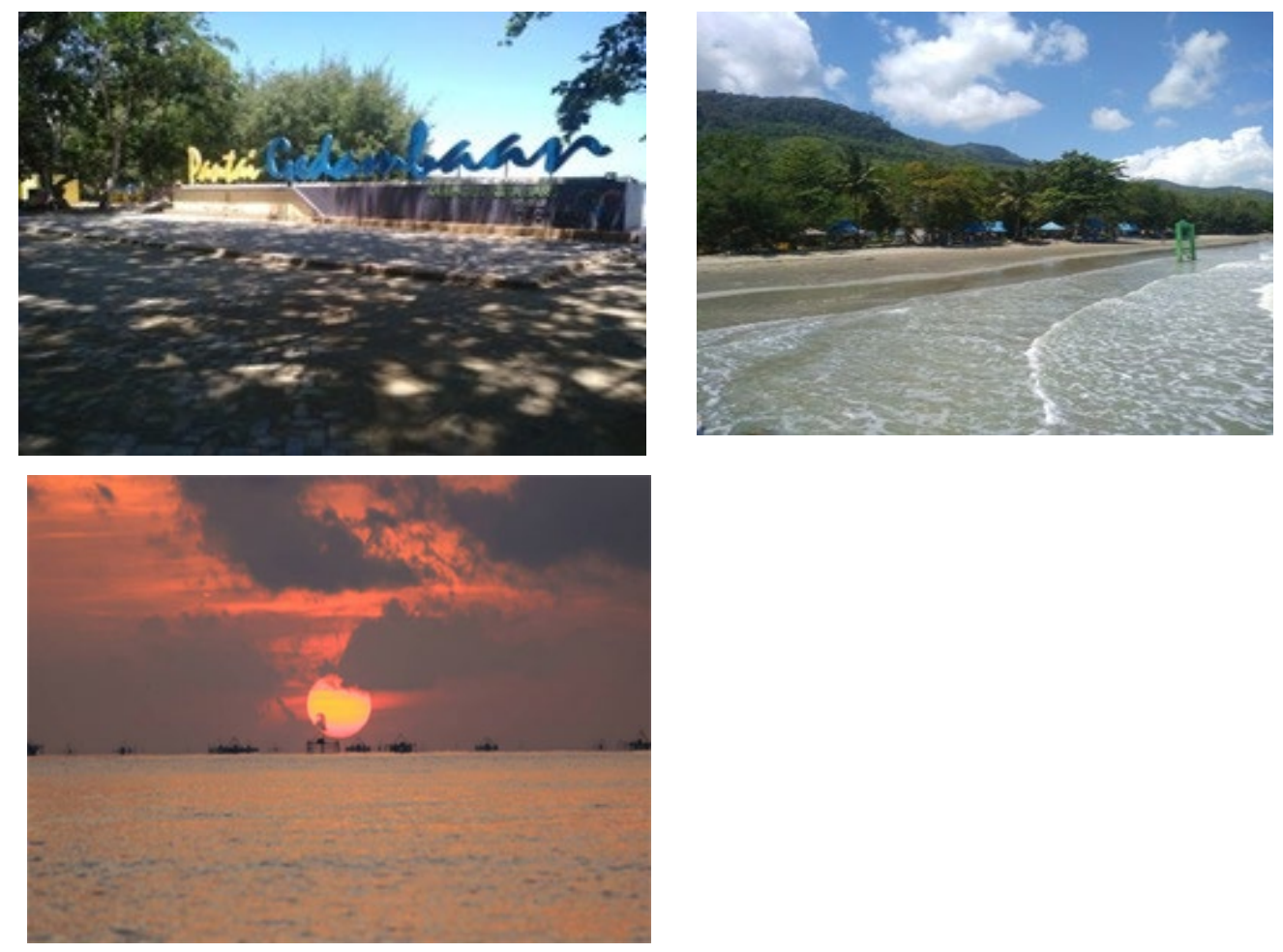

Figure 3 Gedambaan Beach, South Kalimantan, Indonesia 


\section{Community perception of the existence of Gedambaan beach tourism objects}

The perception of the Gedambaan Village community towards the existence of the Gedambaan Tourism Object in Kotabaru Regency based on the ten positive questions is illustrated in detail in Figure 4.

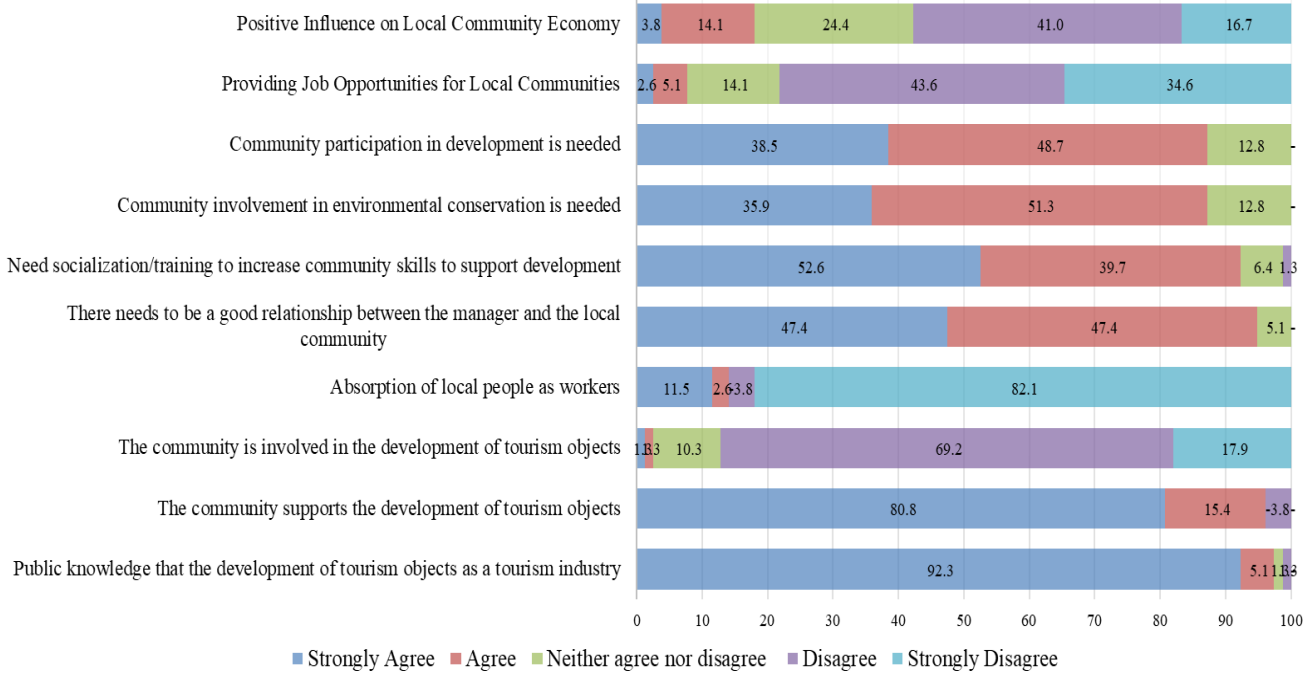

Figure 4 Community perception of the existence of Gedambaan beach tourism objects

The results of the calculation of the score on the weight of the select scale with the frequency of each respondent's answers are presented in Table 2. Table 2 describes the respondents' perceptions on each question item.

\begin{tabular}{|c|c|c|c|c|c|c|c|c|}
\hline \multirow[t]{2}{*}{ Questions } & \multicolumn{5}{|c|}{ Frequency $\times$ Weighted Value } & \multirow[t]{2}{*}{ Total } & \multirow[t]{2}{*}{$\%$} & \multirow[t]{2}{*}{ Category } \\
\hline & SA & A & NAND & D & SD & & & \\
\hline $\begin{array}{l}\text { Positive impact on the local } \\
\text { economy }\end{array}$ & 15 & 44 & 57 & 64 & 13 & 193 & 49,49 & NAND \\
\hline $\begin{array}{l}\text { Provide job opportunities for local } \\
\text { community }\end{array}$ & 10 & 16 & 33 & 68 & 27 & 154 & 39,49 & D \\
\hline $\begin{array}{l}\text { Need community participation in } \\
\text { development }\end{array}$ & 150 & 152 & 30 & 0 & 0 & 332 & 85,13 & SA \\
\hline $\begin{array}{l}\text { Need community involvement in } \\
\text { environmental conservation } \\
\text { around }\end{array}$ & 140 & 160 & 30 & 0 & 0 & 330 & 84,62 & SA \\
\hline $\begin{array}{l}\text { Need socialization/training to } \\
\text { increase community skills to } \\
\text { support development }\end{array}$ & 205 & 124 & 15 & 2 & 0 & 346 & 88,72 & SA \\
\hline
\end{tabular}




\begin{tabular}{|c|c|c|c|c|c|c|c|c|}
\hline $\begin{array}{l}\text { There needs to be a good } \\
\text { relationship between the manager } \\
\text { and the local community }\end{array}$ & 185 & 148 & 12 & 0 & 0 & 345 & 88,46 & SA \\
\hline Absorption of local people as labor & 45 & 8 & 0 & 6 & 64 & 123 & 31,54 & D \\
\hline $\begin{array}{l}\text { The community is involved in the } \\
\text { development of tourism objects }\end{array}$ & 5 & 4 & 24 & 108 & 14 & 155 & 39,74 & D \\
\hline $\begin{array}{l}\text { The community supports the } \\
\text { development of tourism objects }\end{array}$ & 315 & 48 & 0 & 6 & 0 & 369 & 94,62 & SA \\
\hline $\begin{array}{l}\text { Public knowledge that the } \\
\text { development of tourism objects as } \\
\text { a tourism industry }\end{array}$ & 360 & 16 & 3 & 2 & 0 & 381 & 97,69 & SA \\
\hline
\end{tabular}

Table 2 shows the community views that the existence of Gedambaan Beach Tourism Objects did not have a positive impact on their household economy (score $193=$ NAND), this was strongly supported by their perception that the existence of Gedambaan Beach Tourism could not open up job opportunities for them (score 123 = D) because all managers were employees of the Kotabaru District government. This was inseparable from the condition of the level of education of the local community which was relatively low ( $42 \%$ finished elementary school).

The low level of education almost occurs in people in all coastal areas in Indonesia which makes it difficult for them to be able to enter directly as managers or workers. Prihandoko et al stated that fishermen in the North Coast region in West Java on average only attended formal education for about 5 years or the equivalent of 5th-grade elementary school (Prihandoko et al. (2012)). Generally fishermen around and out of the area has low knowledge (Sofia (2017)). In Most beach resorts can open business opportunities such as parking services, mat rental services, bathing places, and stalls to the surrounding community according to their capital capabilities and skills. However, in the Gedambaan Beach Tourism area, Kotabaru Regency, the community felt that the existence of this beach tourism object did not provide new business opportunities for them, it could be seen from the results of the analysis which show a total score of 154 or in the category that states they disagreed (D) on the question stating whether the community can make the area a tourist attraction as a new business opportunity for them. This condition was different from Asmara Beach tourism in Jorong Regency which has a positive impact on improving the community's economy as evidenced by the results of the analysis obtained $65.7 \%$ of respondents strongly agree and agree, $26.0 \%$ neither agreed nor disagree and $8.3 \%$ strongly disagree and disagree. The existence of beach tourism provides business opportunities to 166 people ( $>10 \%$ of productive age) who are involved in user fees, security, parking management, homestay business, food and beverage shops, and public facilities services such as bathrooms and toilets (Hidayat and Agusliani (2020)). This positive impact on job opportunities and business opportunities for the surrounding community was also conveyed by Hermawan (2016) who researched the Nglanggeran Tourism Village and Fyka et al. (2018) who examined Bokori Island Tourism, Soropia District. Even according to Sahir et al. (2014) besides opening job opportunities and business opportunities the existence of Camplong Beach tourism, Sampang Madura Regency is also able to improve the quality of local human resources with various training and increase local revenue. The results of a study explaining that the existence of coastal tourism has a positive 
impact on the local economy with community involvement have also been carried out by previous study (Andriyani et al. (2012); Cahyo (2014); Dewi (2014); Laksono and Mussadun (2014).

Community involvement in development is necessary, as is the development of coastal tourism. Based on the results of the calculation of the score from the Likert scale, it was found that the people of Gedambaan Village, Kotabaru Regency were of the view that the development of this tourism area needs involvement $(330=\mathrm{SA})$ and local community participation (332 = SA) as well as good relations between managers and the surrounding community $(345=\mathrm{SA})$. But unfortunately, the local community felt that they were not involved $(155=\mathrm{D})$ even though they felt very supportive of the development of this coastal tourism perspective $(369=\mathrm{SA})$. The tourism awareness group (POKDARWIS) was originally formed but is now no longer active because they felt that the local government was not serious about involving and making it a partner in the development of this coastal tourism area.

Based on the analysis of community perceptions, the Kotabaru Regency government needs to evaluate the governance of this Gedambaan Beach tourist attraction so that the surrounding community can be involved and build togetherness in the management and development of the area while at the same time being able to accept the results of this development to improve the economic conditions of their households apart from income. area. In addition, to increase the Regional Original Income, the community should also be able to feel the benefits of increasing these tourist attractions in improving and distributing community welfare (Zakiah (2019)). Local communities are more aware of the potential that exists in their area (Mahbub et al. (2018)) so that the community cannot be ignored in the development of tourism activity. Policies that prioritize local communities can reduce the number of unemployed in the region (Hadi (2019)). According to Palimbunga, the involvement of the surrounding community can be done at the planning stage where the community is allowed to have an opinion and at the program implementation stage by providing technical guidance to strengthen skills (Palimbunga (2018)).

The lack of quality education can be overcome with training such as homestay/how to receive guests, cooking training, tour guide training, and outbound training (Pamungkas and Muktiali (2015)) or training that produces handicrafts as typical souvenirs. So that person who initially does not have the skills to be able to produce innovations to improve their quality of life. This was potentially done because the people of Gedambaan Village themselves strongly agree that skills training was very necessary for them (346 = SA) and they were very aware that the development of tourism objects is a tourism industry (381 = SA) which continues to require development so that visitors feel comfortable enjoying the natural beauty of the place.

\section{CONCLUSIONS AND RECOMMENDATIONS}

The community around the Gedambaan Beach tourist attraction perceives that the existence of the tourism area did not have a positive impact on the local economy because there were no job opportunities and business opportunities for them. The local community also considers that the manager of the tourism area did not involve the community in the management and development of the tourism area. Meanwhile, the local community views that it was necessary to have community participation, cooperation, and support so that the management and development of the area could have a positive impact on the household economy of the 
surrounding community in addition to increasing the Regional Original Income. The local government of Kotabaru Regency needs to review the management policy of the Gedambaan beach tourism area which is more oriented towards the involvement and empowerment of the local community.

\section{REFERENCES}

Andriyani, I., Hardi, E., \& Husnita, L. (2012). Socio-economic changes in the community after the development of maritime tourism in the Sikakap Islands, Mentawai Regency. Jurnal Ilmu Sosial Mamangan, 1(2), 95-101 [in Indonesia with english abstract]. Retrieved from https://doi.org/10.22202/mamangan.v1i2.1355

Cahyo, A. (2014). The Impact of Teleng Ria Beach Tourism on the Economy of Fishermen's Households in Teleng Village, Pacitan Regency, East Java. Dissertation. University of Brawijaya, Indonesia [in Indonesia].

Dewi, K. (2014). The Impact of the Development of Maritime Tourism on the Economy of the Coastal Community of Batu Bara. Dissertation. University of Medan State, Indonesia [in Indonesia].

Fyka, S.A., Yunus, L., Limi, M.A., Hamzah, A., \& Darwan. (2018). Analysis of the impact of Bokori Island tourism development towards the Bajo social economic conditions (case study in the village Mekar Soropia District). Habitat, 29(3), 106-112 [in Indonesia with english abstract]. Retrieved from https://doi.org/10.21776/ub.habitat.2018.029.3.13

Hadi, M.A. (2019). Community Perceptions Regarding Economic, Social, Cultural Impacts and Development of Tourism Villages in Gunung Kidul Regency. Thesis. University of Muhammadiyah Yogyakarta, Indonesia [in Indonesia].

Hermawan, H. (2016). The impact of Nglanggeran tourism village development on the local community economy. Jurnal Pariwisata, III(2), 105-117 [in Indonesia with english abstract].

Hidayat, A.S. \& Agusliani, E. (2020). Beach tourism, whether benefit or disaster for coastal fisherman of Tanah Laut Regency, South Kalimantan Province. AACL Bioflux, 13(3), 2319-2402. Retrieved from http://www.bioflux.com.ro/docs/2020.1383-1393.pdf

Irhammi, M. (2020). Gedambaan Beach area mountain Sanggraloka Kotabaru South Kalimantan. Journal of Architecture, 9(2), 106-111 [in Indonesia with english abstract]. $\quad$ Retrieved from https://doi.org/10.20527/lanting.v9i2.687

Khrisnamurti, K., Utami, H., \& Darmawan, R. (2017). Tourism impact on the environment in Tidung Island, Seribu Islands. Kajian, 21(3), 257-273 [in Indonesian with english abstract].

Laksono, A.N. \& Mussadun, M. (2014). Impact of ecotourism activities on Karimunjawa Island based on public perception. Teknik PWK (Perencanaan Wilayah Kota), 3(2), 262-273 [in Indonesia]. Retrieved from https://ejournal3.undip.ac.id/index.php/pwk/article/view/5048

Lopes, P.F., Pacheco, S., Clauzet, M., Silvano, R.A., \& Begossi, A. (2015). Fisheries, tourism, and marine protected areas: Conflicting or synergistic interactions? Ecosystem Services, 16, 333-340. Retrieved from https://doi.org/10.1016/j.ecoser.2014.12.003 
Mahbub, A.S., Wahyunira, A., \& Achmad, A. (2018). Community perceptions of the karst ecotourism development plan in Sambueja Village, Simbang District, Maros Regency. Jurnal Perennial, 14(2), 51-60 [in Indonesia with english abstract]. Retrieved from https://doi.org/10.24259/perennial.v14i2.5648

Maliao, J.R., Tirol, P.Y., \& Alcedo, R.M.J. (2017). Ecotourism in a small insular fishing village in the tropics: Bane or boon? Journal of Coastal Zone Management, 20(Suppl.2), 56.

Metri, E., Oktorini, Y., \& Mardhiansyah, M. (2018). Community perception on ecotourism development of Guruh Gemurai waterfall at Kasang Village Kuantan Mudik Subdistrict Kuantan Singingi Regency. Jurnal UR, 5(1), 1-11 [in Indonesia with english abstract].

Palimbunga, I.P. (2018). Community involvement in tourism development in Tabalansu tourism village, Papua. Jumpa, 5(1), 193-210 [in Indonesia with english abstract].

Pamungkas, I.T.D. \& Muktiali, M. (2015). The influence of the existence of the Karangbanjar tourism village on changes in land use, the economy and the social community. Teknik PWK (Perencanaan Wilayah Kota), 4(3), 361-372 [in Indonesia]. $\quad$ Retrieved from https://ejournal3.undip.ac.id/index.php/pwk/article/view/9085

Prihandoko, S., Jahi, A., Gani, D.S., Purnaba, I.G.P., Adrianto, L., \& Tjitradjaja, I. (2012). Social and economic condition of artisanal fishery in the North Coast of West Java Province. Jurnal Penyuluhan, 8(1), 82-91 [in Indonesia with english abstract]. $\quad$ Retrieved from https://jurnal.ipb.ac.id/index.php/jupe/article/view/9896

Regional Development Planning Agency of Kotabaru Regency. (2017). Regional Regulation (PERDA) No. 8 of 2018 concerning the Master Plan for Tourism Development of Kotabaru Regency for 2018-2025. Retrieved from https://peraturan.bpk.go.id/Home/Details/94075/perda-kab-kotabaruno-8-tahun-2018 (Access 20 October 2021).

Riduwan \& Sunarto. (2013). Introduction to STATISTICS. Alfabeta Publisher. Bandung, Indonesia [in Indonesian].

Sahir, Indahsari, K., \& Oktavianti, H. (2014). Analysis of the role of Camplong Beach tourism on the welfare of local people. Media Trend, 9(2), 181-195 [in Indonesia with english abstract].

Sofia, L.A. (2017). Fishermen's perception and participation in fisheries resources conservation of Batungap swamp in Tapin Regency, South Kalimantan, Indonesia. AACL Bioflux, 10(6), 1618-1626. Retrieved from https://www.bioflux.com.ro/docs/2017.1618-1626.pdf

Suardana, I.W. \& Sudiarta, I.N. (2017). Impact of tourism to poverty in tourism destination: Pro poor tourism management approach. Journal of Business on Hospitality and Tourism, 2(1), 65-75. Retrieved from https://doi.org/10.22334/jbhost.v2i1.42

Sugiyono. (2011). Quantitative, Qualitative and R\&D Educational Research Methods. Alfabeta Publisher. Bandung, Indonesia [in Indonesian].

Surwiyanta, A. (2003) Impact of tourism development on socio-cultural and economic life. Media Wisata, 2(1), 33-42 [in Indonesia]. 
UKK BPP. (2017). Final Report, Making DED for Gedambaan Beach Tourism Object in Kotabaru Regency in 2017. Faculty of Engineering. Brawijaya University. Malang.

Wu, C.C. \& Tsai, H.M. (2016). Capacity building for tourism development in a nested social-ecological system-A case study of the South Penghu Archipelago Marine National Park, Taiwan. Ocean \& coastal management, 123(2016), 6673. Retrieved from https://doi.org/10.1016/j.ocecoaman.2016.02.001

Zakiah, H. (2019). Management of Gedambaan Beach Tourism Objects as One of the Regional Original Income (PAD) of Kotabaru Regency. Thesis in Islamic Economics and Business. UIN Antasari Banjarmasin, Indonesia [in Indonesia]. 